\title{
O DIREITO FUNDAMENTAL AO TRABALHO SOB A PERSPECTIVA DA DIGNIDADE DA PESSOA HUMANA
}

\author{
THE FUNDAMENTAL RIGHT TO WORK IN A \\ PERSPECTIVE OF HUMAN DIGNITY
}

JOÃO LUIZ BARBOZA ${ }^{1}$

\begin{abstract}
RESUMO: O homem sempre dependeu de alguma atividade que the proporcionasse os meios de sobrevivência. A sua atividade produtiva evoluiu da atividade grupal de subsistência para o trabalho individual. O trabalho representa, na atualidade, um direito social fundamental, necessário à garantia de acesso aos recursos essenciais para uma vida digna. Os Estados vêm enfrentando dificuldades para garantir esse direito, porém devem envidar esforços para que cada indivíduo possa ter acesso ao trabalho.
\end{abstract}

PALAVRAS-CHAVE: Trabalho; Direitos Fundamentais; Dignidade da Pessoa Humana.

ABSTRACT: Man has always depended on some activity that would provide him with the means of survival. His productive activity evolved from subsistence group activity to individual work. The work represents nowadays a fundamental social right, necessary to ensure access to essential resources for a dignified life. States are struggling to ensure that right for all, but shall endeavor to ensure that each individual may have access to work.

KEYWORDS: Work; Fundamental Rights; Human Dignity.

SUMÁRIO: Introdução; 1. Breve Histórico sobre a Evolução do Trabalho Humano Individual; 1.1 O Surgimento da Burguesia; 1.2 A Precarização do Trabalho; 2. A Exploração do Trabalho Escravo; 3. O Trabalho nas Constituições Brasileiras; 4. Breves Considerações sobre os Direitos Fundamentais; 4.1 Direitos Fundamentais e suas Gerações; 5. O Trabalho como Sustentação da Dignidade da Pessoa Humana; Conclusões; Referências Bibliográficas.

Artigo recebido em 10.01.2013. Pareceres emitidos em 10.03.2013 e 11.06.2013.

Artigo aceito para publicação em 23.06.2013.

${ }^{1}$ Doutorando em Direito Constitucional pela Pontifícia Universidade Católica, Campus Perdizes, São Paulo/SP. Mestre em Direitos Fundamentais pelo UNIFIEO - Centro Universitário FIEO, Campus Narciso Sturlini, Osasco/SP. Bacharel em Direito pela Universidade Paulista - UNIP, Campus Cidade Universitária, São Paulo/SP. Bacharel em Administração de Empresas pelo UNIFIEO, Campus Narciso Sturlini, Osasco/SP, com Pós-graduação (Licenciatura) pela Faculdade Campos Salles, Campus Lapa, São Paulo/SP. Advogado - SP. Professor de Graduação da Faculdade Nossa Cidade, Campus Carapicuíba, São Paulo/SP. joao@amarojulina.com.br 
SUMMARY: Introduction; 1. Brief Historical Considerations About Individual Human Work; 1.1 The Emergence of the Bourgeoisie; 1.2 The Precariousness of Work; 2. The Exploitation of Slave Labor; 3. Work in Brazilian Constitutions; 4. Brief Observations on the Fundamental Rights; 4.1 Fundamental Rights and their Generations; 5. Work as Support the Dignity of the Human Person; Conclusions; References.

\section{INTRODUÇÃO}

O propósito do presente texto é enfrentar o tema do trabalho humano enquanto direito fundamental e como atividade indispensável para proporcionar a cada indivíduo o meio de acesso aos recursos básicos necessários para uma existência digna.

Partir-se-á do pressuposto de que o ser humano sempre dependeu de alguma ação que lhe proporcionasse a aquisição dos meios de sobrevivência, ainda que fosse a simples colheita do que lhe era proporcionado pela mãe natureza.

A pesquisa buscará demonstrar que por um longo período a atividade produtiva do homem ficou restrita ao uso da terra para produção de alimentos destinados ao grupo ao qual estava vinculado e alguma produção artesanal rudimentar voltada à subsistência, não havendo um interesse individual a ser perseguido.

Evidenciar-se-á que a partir dos primeiros sinais do capitalismo, o homem foi se desvinculando da atividade grupal de subsistência e passando a depender do trabalho individual, e que com o surgimento da classe burguesa ocorrem as revoluções políticas e mudança na forma de constituição do poder do Estado, quando ganham importância as liberdades individuais.

À evidência de que o trabalho individual situa o homem comum em um cenário de submissão ao poder do capital, que passa a dominar os meios de produção, proporcionando a crescente desigualdade entre trabalhadores e proprietários do capital e dos bens de produção, é que se justificará a intervenção do Estado nas relações de trabalho, de forma a promover a proteção dos direitos do trabalhador. Por conta de tais transformações o trabalho ganha status de direito fundamental.

Constatar-se-á que a positivação do trabalho como direito fundamental e a sua valorização como fundamento da Ordem Econômica da atual Constituição brasileira reclama do Estado a defesa desse direito como meio de garantia da dignidade da pessoa humana, principalmente tendo em conta as características inerentes à sociedade brasileira, qual seja, ter grande parte com baixo grau de educação formal e com consequente baixa capacidade competitiva no campo das oportunidades de trabalho.

Para tanto, o grande desafio consistirá na busca da superação das dificuldades encontradas para proporcionar a cada indivíduo uma oportunidade de trabalho que Ihe possibilite auferir rendimentos mínimos necessários ao seu sustento e de sua família em condições dignas de vida. 


\section{BREVE HISTÓRICO SOBRE A EVOLUÇÃO DO TRABALHO HUMANO INDIVIDUAL}

Ao se pretender estudar e entender o desenvolvimento da humanidade ou de qualquer de suas atividades é inevitável deparar-se com a dificuldade para encontrar a ponta do fio da meada, a partir da qual se poderá guiar um estudo alicerçado por uma razoável sequência na cronologia da história. O mesmo se verificará nessa nossa busca das razões que tornaram o homem comum atual um ser totalmente dependente do seu trabalho individual.

Inicialmente, pode-se deduzir, sem grandes esforços, que em tempos remotos o homem não se via compelido a produzir com suas próprias forças os víveres essencialmente necessários à manutenção das condições mínimas de sobrevivência ${ }^{2}$. Até por que ainda não se faziam presentes as necessidades que se iriam criando somente a partir dos futuros estágios da civilização.

Mas, para o nosso desiderato, qual seja estabelecer os fundamentos históricos da atual dependência do homem relativamente ao seu trabalho, avaliamos como fundamental o entendimento das mudanças ocorridas na organização das relações que se estabelecem na vida social, desde a Antiguidade até os dias atuais, quando está plenamente consolidado o trabalho individual como fundamental para garantia da sobrevivência e, consequentemente, como supedâneo da dignidade humana.

Nos níveis hodiernos, fica impossível imaginar a vida em sociedade sem a atividade laboral organizada, pela qual cada indivíduo busca satisfazer, desde as suas necessidades básicas até os anseios e expectativas artificialmente criadas pelos mais diversos meios de estímulos a que está exposto.

$\mathrm{O}$ desiderato de entender a origem e o desenvolvimento da atividade laboral nos moldes em que se encontra não é menos estimulador do que desafiador. É certo que se terá de aceitar as considerações externadas por alguns daqueles que se dedicam aos estudos da história da humanidade, de que é impossível encontrar evidências de tudo que se procura constituir em informações, restando sempre um caráter dedutível, tanto mais acentuado quanto mais se retrocede na história, tendo como premissa a verdade apontada por Marx e Engels de que a condição primeira de toda história é, naturalmente, a existência de seres humanos vivos ${ }^{3}$. É com este entendimento que se buscará compreender o desenvolvimento da atividade laboral, com os contornos ora propostos em rápido escorço.

\footnotetext{
${ }^{2}$ Engels, ao tratar do que denomina fase inferior do Estado selvagem, se refere à "Infância do gênero humano. Os homens permaneciam, ainda, nos bosques tropicais ou subtropicais e viviam, pelo menos parcialmente, nas árvores; só isso explica que continuassem a existir no meio de grandes feras selvagens. Os frutos, as nozes e as raízes serviam de alimento; o principal progresso desse período é a formação da linguagem articulada" ENGELS, Friedrich. A Origem da Família, da Propriedade e do Estado. (Tradução de H. Chaves). Lisboa: Editora Presença, 1976, p. 32.

${ }^{3}$ MARX, Karl; ENGELS, Friedrich. As Condições das Transformações Históricas p. 67-83. In IANNI, Octavio. Teorias de Estratificação Social - Leituras de Sociologia. São Paulo: Companhia Editora Nacional, 1973, p. 67.
} 
Imaginar que nos primórdios o homem não necessitava despender esforços para suprir suas necessidades vitais, como dito, não constitui tarefa difícil. A natureza provia a todos com o que necessitavam para a sobrevivência, sem que para tanto tivessem que mover esforços além do necessário para a simples cata. Não havia necessidade de produção, pois de tudo se dispunha em abundância. Tampouco é difícil imaginar a ausência de grandes ambições ao se dispor, em tal estágio, do quantum adequado à sobrevivência. A própria noção de trabalho individual não seria concebível, na medida em que o caráter gregário do ser humano estava na base da constituição dos grupos, acentuadamente na forma de convivência ${ }^{4}$. Considerações relativas ao homem enquanto indivíduo começarão a se fazer presentes somente em um futuro ainda distante.

$\mathrm{Na}$ fase das tragédias gregas, a partir do século $\mathrm{V}$ a. C., encontramos certa introspecção nos subterrâneos da alma humana ${ }^{5}$. Porém, não se fazia presente ainda a noção de indivíduo; este era parte de um todo - o grupo - ao qual pertencia, sem que se pudesse imaginar qualquer interesse individualista.

Se nem mesmo a noção de indivíduo estava presente no ideário de então, a noção de trabalho individual como hoje a temos é de concepção ainda mais recente, vez que o trabalho estava associado a um fim genérico desprovido de qualquer interesse particularizado ${ }^{6}$.

Entretanto, os gregos do período helênico já dispunham de certa organização econômica, além da política. E nessa organização as atividades artesanais e comerciais se mantinham com certa importância no seio da sociedade, se caracterizando até mesmo como forma de distinção. Mas, já aí, o trabalho manual como único meio de sobrevivência servia de referência para uma classe que era vista como inferior, vez que gerava uma dependência da clientela, o que caracterizava carência dos elementos de distinção, como a

\footnotetext{
${ }^{4}$ Como ensina Ferrari, "O trabalho, nos primórdios, deu-se pela cooperação de marido e mulher cooperação social no clã, nas famílias patriarcais, reunindo sob o mesmo teto, parentes, escravos ou servos, para desenvolver-se entre clãs da mesma tribo ou de tribos diferentes". FERRARI, Irani. História do Trabalho (p. 13-72). In FERRARI, Irani; NASCIMENTO, Amauri Mascaro; MARTINS FILHO, Ives Gandra da Silva. História do Trabalho, do Direito do Trabalho e da Justiça do Trabalho. São Paulo: LTr, 1998, p. 24.

${ }^{5}$ COMPARATO, Fábio Konder. A Afirmação Histórica dos Direitos Humanos. 4. ed., São Paulo: Saraiva, 2006, p. 9.

6 "É verdade que, na prática, o trabalho era uma realidade vivenciada para os gregos. Mas, de Hesídio a Aristóteles, as diferentes atividades relacionadas a ele sempre foram evocadas em sua pluralidade e em função de sua finalidade particular. Elas compreendiam naturalmente os trabalhos de produção agrícola e artesanal, assim como as atividades comerciais, mas também outras 'profissões' como as de poeta, de médico e adivinho. Ora, essas ocupações jamais foram percebidas como a parte de um todo nem descritas como as facetas de uma noção global compatível com a nossa". MIGEOTTE, Léopold. Os Filósofos Gregos e o Trabalho na Antiguidade. In MERCURE, Daniel; SPURK, Jan. (orgs). O Trabalho na História do Pensamento Ocidental. Tradução de Patrícia Chittoni Ramos e Sônia Guimarães Taborda. Petrópolis, RJ: Vozes, 2006, p. 18.
} 
propriedade ou capital aptos a proporcionar os ganhos econômicos garantidores de destaque social ${ }^{7}$.

A visão coletivista do trabalho perdurará por muito tempo e a sua superação será fruto de transformações profundas ocorridas a partir da Idade Média, quando, então, o homem começa a ser considerado em sua igualdade como pessoa ${ }^{8}$.

É, realmente, no transcorrer da Idade Média que se verificarão as grandes mudanças nas relações sociais, cujos reflexos se farão sentir também nas relações estabelecidas entre indivíduo e o trabalho. Naquele período, que se estende do final do século IV ao século $X V$, predominou o regime servil - o feudalismo -, em que a ascensão social era muito restrita.

O feudalismo caracterizou uma forma de ocupação e divisão das terras muito eficiente do ponto de vista da subsistência'. As regras que prendiam os servos aos feudos estavam bem estipuladas, inclusive restringindo a possibilidade de casamento dos servos e de seus filhos aos domínios do senhor feuda ${ }^{10}$. Assim, aqueles que detinham a posse da terra como dignatários - os senhores feudais - mantinham em seus domínios os servos, cuja situação

\footnotetext{
7 "Vemos, portanto, que para além das convicções moralistas e de clivagens sociais, a opinião dos gregos sobre as profissões dependia de inúmeros fatores, dentre os quais a riqueza desempenhava um papel importante. Afinal de contas, o trabalho manual não era menosprezado em si, mas na medida em que se impunha como uma necessidade. A situação mais degradante, que os filósofos apresentavam como uma perda de liberdade e uma forma de servidão, era o estado de dependência a que podia levar a pobreza: aquela do pequeno artesão-lojista sempre à mercê do cliente e, principalmente, aquela do thète, figura clássica do homem sem recursos que devia alugar seu trabalho a terceiros". MIGEOTTE, Léopold. Op. Cit., p. 33.

${ }^{8}$ Comparato nos dá conta de que "Foi, de qualquer forma, sobre a concepção medieval de pessoa que se iniciou a elaboração do princípio de igualdade essencial de todo ser humano, não obstante a ocorrência de todas as diferenças individuais ou grupais, de ordem biológica ou cultural. E é essa igualdade de essência da pessoa que forma o núcleo do conceito universal de direitos humanos. COMPARATO. Op. Cit., p. 20.

${ }_{9}$ A divisão em feudos caracterizou a forma de ocupação da Europa pelos Bárbaros após a queda do Império Romano. "A maioria das terras agrícolas da Europa ocidental e central estava dividida em áreas conhecidas como 'feudos'. Um feudo consistia apenas de uma aldeia e as várias centenas de acres de terra arável que a circundavam, e nas quais o povo da aldeia trabalhava. $\mathrm{Na}$ orla da terra arável havia, geralmente, uma extensão de prados, terrenos ermos, bosques e pastos. Nas diversas localidades, os feudos variavam de tamanho, organização e relações entre os que os habitavam, mas suas características principais se assemelhavam, de certa forma." HUBERMAN, Leo. História da Riqueza do Homem. Rio de Janeiro: LTC Editora, 1986, p. 3.

${ }^{10}$ As raízes da históricas da cultura ocidental estão fincadas predominantemente na Europa, razão pela qual esta se estabelece como ambiente apropriado para a concentração do ponto de partida dos nossos estudos. A Europa oferecia uma base apropriada para regime feudal, dadas as características favoráveis, tanto do ponto de vista climático como da qualidade do solo. Le Goff assim a descreve; "A Europa é o final do continente euro-asiático. Apresenta uma diversidade de solo e de relevo que ancoram na geografia a diversidade que é uma característica da Europa. Mas, ao mesmo tempo, elementos geográficos unificadores se impõem. A extensão das planícies que favorecerá a cultura dos cereais desenvolvida pela Idade Média e que continua sendo hoje um dos pontos fortes, embora controvertido, da economia europeia comum." LE GOFF, Jacques. As Raízes Medievais da Europa. Tradução de Jaime A. Clasen. Petrópolis, RJ: Vozes, 2007, p. 20.
} 
era praticamente de cativos, pois que o vínculo se estabelecia com base na proteção que daqueles recebiam.

A agricultura era, portanto, a base da economia, predominantemente voltada para a subsistência. Em troca da proteção os servos tinham para com os senhores feudais o dever de fidelidade, assim como o dever de pagar pesados tributos pelo uso da terra que lhes era destinada, geralmente representado por parte de tudo que produziam em sua gleba. Além disso, deveriam trabalhar uma parte do tempo nas terras exclusivas do senhor feudal, pagando assim a corveia.

O feudalismo se sustentou por longo tempo em função da sua própria lógica, pois seu funcionamento proporcionava segurança e atendimento às necessidades dos servos e, ao mesmo tempo, os maiores interessados - os senhores feudais - se viam em situação cômoda com os tributos que recebiam e a obediência que Ihes era dedicada por aqueles. Assim, tudo concorria para que o regime continuasse estável, livre de ameaças de movimentos reivindicatórios significativos. Para tanto, muito contribuiu a Igreja católica, que por meio do cristianismo pregava o desapego aos bens materiais, propugnando pela ligação do homem a Deus através da entrega pela fé. Seu interesse na manutenção do feudalismo era grande, vez que era ela, a própria Igreja, detentora de grandes propriedades e, portanto, beneficiária desse regime ${ }^{11}$.

É de se notar que o regime feudal se fundava na forma de produção familiar, é dizer, não se oferecia ambiente adequado à transição para um regime de trabalho de interesse individual assalariado, o que só se verificará mais adiante com o surgimento dos primeiros sinais do capitalismo ${ }^{12}$. Antes, porém, alguns séculos transcorrerão até que surjam significativos abalos na estrutura de sustentação do sistema feudal.

O artesanato e seu desenvolvimento, os pequenos comércios locais, inicialmente baseado nas trocas, também para atendimento das necessidades

\footnotetext{
11 "Era de esperar que a Igreja liderasse um movimento de libertação dos servos. Mas, pelo contrario, o principal adversário da emancipação, tanto na cidade como no campo, não foi a nobreza, e sim a Igreja. Numa época em que a maioria dos senhores havia compreendido que era melhor, para seus próprios interesses, dar liberdade ao servo e contratar trabalhadores livres com remuneração diária, a Igreja ainda se manifestava contra a emancipação." HUBERMAN. Op. Cit., p. 47.

12 "A ideologia do individualismo, erigida sob as promessas da libertação das amarras das relações pessoais encetadas no feudalismo já historicamente decadente, aponta para a emersão de uma nova sociedade estruturada sob o modo de produção capitalista, na qual o homem é tomado como indivíduo isolado, igual aos demais em oportunidades, capaz de conquistar com seu próprio esforço - trabalho - as condições de sua subsistência, a partir do conhecimento dos seus interesses e da garantia de um direito de propriedade. O homem é produtor de mercadorias destinadas à circulação. Consagrou-se, então, o liberalismo econômico e político". Adacy Rachid Coutinho. A Autonomia Privada: em busca da defesa dos direitos fundamentais dos trabalhadores. p. 159-173. In SARLET, Ingo Wolfgang. (organizador). Constituição, Direitos Fundamentais e Direito Privado. Porto Alegre: Livraria do Advogado, 2010, p. 167-168.
} 
de subsistência, com o tempo evoluíram e contribuíram para modificações profundas. Entretanto, os primeiros passos já haviam sido dados na direção de uma mudança de paradigma na relação entre o homem e o trabalho. Aos poucos o trabalho começará a perder aquela característica de projeção da pessoa daquele que o executa, como afirmada na visão marxista, trazida por Spurk, segundo a qual o trabalhador se exterioriza e se objetiva no produto de seu trabalho ${ }^{13}$.

\subsection{O Surgimento da Burguesia}

Os historiadores identificam uma fase pré-capitalista que, ainda no regime feudal, se encontra associada ao artesanato e o comércio baseado nas trocas dos excedentes da produção ${ }^{14}$. Os artesãos, que antes se ocupavam da confecção de produtos voltados exclusivamente ao atendimento dos feudos, começam a promover as trocas dos excedentes. Como não havia o trabalho assalariado, o artesão que se ia desvinculando da atividade agrícola passava a ser o dono da própria produção. Verifica-se a partir daí uma mudança fundamental: o trabalho começa a se desvincular da terra. A agricultura, embora comece a experimentar um grande desenvolvimento, proporcionado por novas técnicas, ao mesmo tempo começa perder a hegemonia no processo produtivo.

Gradativamente o comércio vai se desenvolvendo, possibilitando certa independência dos artesãos, que vão se desvinculando dos feudos e formando os burgos. O também gradativo aumento da população faz com que a vida citadina ganhe cada vez maior importância.

Aos poucos o comércio vai se tornando uma atividade lucrativa, que passa a promover o desenvolvimento dos centros urbanos. As relações comerciais se expandem para outras regiões. Tudo vai contribuindo para o surgimento de uma nova classe identificada como burguesia, e para a decadência do sistema feudal. O trabalho ganha, então, contornos que se projetarão para um futuro longínquo ${ }^{15}$.

\footnotetext{
${ }^{13}$ SPURK, Jan. A Noção de Trabalho em Karl Marx (p. 189-211) In MERCURE, Daniel; SPURK, Jan. (orgs). O Trabalho na História do Pensamento Ocidental. Tradução de Patrícia Chittoni Ramos e Sônia Guimarães Taborda. Petrópolis, RJ: Vozes, 2006, p. 195.

${ }^{14}$ Como aponta Ripert: "Nos séculos 12 e 13, o movimento criado pelas Cruzadas e pela descoberta de novas rotas marítimas, o afluxo de metais preciosos, o estabelecimento de feitorias, a expansão das feiras, o aperfeiçoamento dos métodos bancários, a extensão dos mercados, tudo isso marca na Europa a transformação da economia antiga. Encontra-se em presença de 'um nascente capitalismo". RIPERT, Georges. Aspectos Jurídicos do Capitalismo Moderno. Campinas, SP: Red Livros, 2002, p. 27-28.

${ }^{15}$ Le Goff evidencia muito bem essa perspectiva: "O século XIII viu também se firmar uma importante mudança de mentalidade e de comportamento no âmbito essencial da atividade humana em que a tradição medieval é ainda perceptível hoje: o trabalho. Na alta Idade Média, o trabalho tinha status ambíguo; causava problema, sobretudo no mundo monástico. As regras monásticas, a começar pela regra de São Bento, obrigavam os monges a um duplo trabalho. Um trabalho intelectual de cópia de manuscritos e um trabalho econômico de agricultura de subsistência. (...) O progresso tecnológico do trabalho rural, o desenvolvimento do trabalho artesanal nas cidades, a busca de riqueza e de status social elevado graças ao trabalho refletiam
} 
A consequência do aprimoramento do comércio e do artesanato é o desenvolvimento dos núcleos burgueses, que darão origem às cidades. Nestas, a vida se apresenta com características diversas daquela restrita à atividade agrícola dos feudos, pois a atmosfera do feudalismo era a da prisão, ao passo que a atmosfera da atividade comercial na cidade era a da liberdade ${ }^{16}$ e se torna, portanto, cada vez mais atrativa, mormente para aqueles cujas habilidades já os desvinculara totalmente das atividades do campo, da produção agrícola. Uma ainda incipiente reivindicação por liberdade começava a nascer, não no sentido dos ideais que se verificarão nas futuras lutas por liberdades individuais, mas sim no desejo de romper com as amarras feudais que cerceavam as práticas comerciais, vistas agora como atrativo meio de conquistas de riqueza e da consequente liberdade ${ }^{17}$.

De qualquer forma, iniciara-se uma fase de anseios diversos daquilo que se poderia esperar daquela pacífica população campesina dedicada exclusivamente à produção agrícola dos feudos. As cidades desejam, agora, se autoafirmar como o locus adequado ao desenvolvimento das atividades humanas diferenciadas daquelas estritamente ligadas à agricultura. $\mathrm{O}$ homem passa, então, a ser sujeito de reivindicações nunca antes imaginadas, quais sejam, o reconhecimento da sua capacidade de produzir e de proporcionar o atendimento das necessidades da população citadina, que já se firmara como destinatária dos bens de consumo.

Por outro lado, a população citadina tem necessidades que somente poderão ser supridas por meio da atividade do campo, apta a lhe suprir com gêneros alimentícios sem os quais, evidentemente, não poderá subsistir. Está assim configurada uma certa divisão do trabalho: o campo produzindo gêneros de primeira necessidade e a cidade se ocupando do suprimento de produtos manufaturados ou artesanais ${ }^{18}$.

\footnotetext{
sobre a imagem dele. Viu-se que os mercadores e os universitários foram legitimados por seu trabalho. Os irmãos das ordens mendicantes foram criticados por sua recusa a trabalhar, mas eles se defenderam ao reclamar para o seu apostolado uma forma de trabalho. As classes sociais que mostravam a sua superioridade pela sua abstenção ao trabalho - ociosidade dos contemplativos e dos clérigos, ociosidade dos guerreiros, dos cavaleiros e dos nobres - eram convencidos pela promoção do trabalho na sociedade e na espiritualidade. A atividade guerreira foi apresentada como um trabalho útil para a proteção dos fracos. $O$ apostolado dos clérigos foi, antes mesmo da autodefesa dos mendicantes, reconhecido e elogiado. Todo o mundo da cortesia e da cavalaria se viu ameaçado por essa valorização do trabalho. Apareceu um adágio: O Labor Supera a Proeza." LE GOFF. Op. Cit., p. 210.

${ }^{16}$ HUBERMAN, Leo. História da Riqueza do Homem. Rio de Janeiro: LTC Editora, 1986, p. 27.

17 "Na verdade, as populações das cidades em luta, dirigidas pelas associações de mercadores organizados, não eram revolucionários no sentido que emprestamos à palavra. Não lutavam para derrubar seus senhores, mas apenas para fazê-los abandonar algumas das práticas feudais já gastas pelo uso, que constituíam um estorvo decisivo à expansão do comércio". HUBERMAN. Op. Cit., p. 31.

18 "Quando surgem cidades nas quais os habitantes se ocupam total ou parcialmente do comércio e da indústria, passam a ter necessidade de obter do campo suprimentos de alimentos. Surge, portanto, uma divisão do trabalho entre cidade e campo." HUBERMAN. Op. Cit., p. 42.
} 
Nos século XIII e XIV essa complementariedade já não impedia que a vida no campo se tornasse cada vez menos atrativa em relação às cidades, 0 que começou a desencadear movimentos dos camponeses pela liberdade, e quando ela não era concedida de boa vontade, tentavam tomá-la à força ${ }^{19}$, com uma tendência de agravamento cada vez maior dessa reação surgida sem grandes pretensões. Era, então, uma transformação inevitável já se fazendo presente ${ }^{20}$.

O desenvolvimento das atividades artesanais experimentam especializações que possibilitam a criação de grandes oficinas produtoras, quando começam a surgir também as corporações de ofício e o trabalho assalariado. Com a diminuição da importância dos feudos na economia e a maior possibilidade de obtenção de recursos via cobrança de impostos em dinheiro, os reis passam a ter possibilidades de formação de exércitos de homens remunerados, caracterizando também uma nova forma de trabalho que antes era exercido por simples dever de lealdade.

Um componente importante passa a fazer parte desse cenário: o dinheiro é agora o referencial a que se recorre com todo interesse, pois cria a possibilidade de se acumular e multiplicar riquezas. A moeda tinha o seu valor representado pela sua composição típica em metais preciosos. Como a riqueza dos reinados estava associada à acumulação desses metais os reis descobrem um mecanismo simples para aumentar as suas fortunas, qual seja a redução do valor intrínseco das moedas, por meio da constante redução da quantidade do metal precioso - ouro ou prata - que as compunha ${ }^{21}$.

\footnotetext{
${ }^{19}$ HUBERMAN. Op. Cit., p. 48.

${ }^{20}$ É de importância registrar que a Europa da organização romana fora de vocação urbana, e que a ruralização pós Império Romano foi, nesse sentido, uma regressão, como afirma Le Goff: "A primeira mudança, de ordem econômica, que já foi mencionada, é a ruralização de um mundo que fora fortemente urbanizado pelos romanos. É a ruína das estradas, das oficinas, dos entrepostos, dos sistemas de irrigação, das culturas. É uma regressão técnica que bate particularmente a pedra que deixa o lugar a uma volta à madeira como material essencial na construção. O refluxo da população urbana para a zona rural não enche o vazio deixado pela regressão demográfica. No lugar da cidade, urbs, é a vila, o grande domínio, que se torna a célula econômica e social de base. A unidade de exploração e povoamento é a mansa, de superfície muito variável, mas em geral pequena, capaz de manter apenas uma família." LE GOFF, Jacques. As Raízes Medievais da Europa. Tradução de Jaime A. Clasen. Petrópolis, RJ: Vozes, 2007, p. 47. É o próprio Le Goff quem aponta as características da Europa dos últimos séculos do medievo: "Se durante a Alta Idade Média vimos realizar-se uma Europa rural, no século XIII se impõe uma Europa urbana. A Europa incarnar-se-á essencialmente nas cidades. É aí que acontecerão as principais misturas de população, que se afirmarão novas instituições, que aparecerão novos centros econômicos e intelectuais." LE GOFF. Op. Cit., 143.

${ }^{21} \mathrm{Tal}$ procedimento inflacionava os preços e ia aviltando cada vez mais os ganhos daqueles que agora se dedicavam ao trabalho remunerado. "Tudo que os reis viam, porém, era o lucro imediato que Ihes advinha da desvalorização da moeda. A verdade, porém, é que quando o dinheiro muda de valor o comércio é afetado; quando os preços se elevam, os pobres e os que têm renda fixa são prejudicados - isso podia ter pouca importância para o rei, mas era fundamental para alguns dos seus súditos. A maioria das pessoas, frequentemente até mesmo o rei, não via essa ligação entre desvalorização da moeda e a elevação dos preços." HUBERMAN. Op. Cit., p. 85.
} 
Esse mecanismo provocou grande aviltamento dos salários e precariedade da vida dos trabalhadores, e estes passaram a viver em condições de miséria total, criando uma classe de mendigos que marcou época ${ }^{22}$.

O poder do capital passa, então, a crescer de forma a se tornar a alavanca do desenvolvimento da atividade dos mercadores. As grandes navegações ganham impulso, pois a busca por metais preciosos e as especiarias originários das Índias passa a ser o meio de auferir grandes lucros com o comércio desses bens. Tanto que consta ter surgido por volta dos séculos XVI e $\mathrm{XVII}$ as sociedades por ações, para viabilizar os grandes projetos dos mercadores $^{23}$. O acúmulo dos metais preciosos, que lastreavam as moedas gerou consequências desastrosas para os trabalhadores que dependiam de salários, pois que inflacionando os preços em geral, não deixavam alternativas para aqueles que tinham, agora, como moeda de troca apenas o seu trabalho ${ }^{24}$.

A Idade Média, como demonstrado, havia caracterizado o período da história em que o trabalho humano é convertido de uma atividade voltado para a subsistência do grupo para uma forma de busca da sobrevivência, com a diferença de que agora o indivíduo dependerá cada vez mais da venda da sua força física individual ou, eventualmente, de alguma habilidade particular, para aquisição dos víveres. Doravante, a situação do trabalhador passará a sofrer agravamentos cada vez maiores, de sorte que as revoltas não tardarão a acontecer, pois a força do capital não conhecerá limites.

A classe burguesa passa a conhecer a sua importância e dela fazer uso para a conquista da influência política de que ainda não dispunha, representando agora uma classe média que não existia no feudalismo, cuja

\footnotetext{
${ }^{22} \mathrm{O}$ final da Idade Média foi marcado por um contexto muito desfavorável ao indivíduo que passara a depender do trabalho remunerado para a sua sobrevivência. "Os homens e as mulheres do século $\mathrm{XVI}$, muitas vezes dominados por visões apocalípticas que descem também do céu à terra, resumiram muitas vezes as catástrofes que foi preciso enfrentar pela imagem dos três cavaleiros do Apocalipse: a fome, a guerra e a epidemia. Nenhum desses fenômenos era desconhecido das fases precedentes da Idade Média, mas também tanto a sua intensidade como certos aspectos novos criavam uma impressão inaudita." LE GOFF. Op. Cit., p. 220-221.

${ }^{23}$ "A sociedade por ações foi a resposta dada pelos mercadores nos séculos XVI e XVII ao problema que era levantar os enormes capitais necessários a tão vastos empreendimentos como o comércio com a América, África e Ásia. A primeira sociedade por ações inglesa foi a dos Aventureiros mercadores. Contava com 240 acionistas que entraram, cada um, com 25 libras soma de certa importância, na época." HUBERMAN. Op. Cit., p. 91.

${ }^{24}$ As consequências sofridas pelos trabalhadores em decorrência da inflação de preços, tão presentes na atualidade, já se faziam muito presentes por aquela época. "As revoluções do período, que trouxeram novo poder político à burguesia, estavam intimamente ligadas à revolução dos preços. Os salários dos trabalhadores também sofreram. Um período de alta de preços é quase sempre também um período de elevação de salários e, portanto, seria de esperar que no fim de tudo desse certo. Mas há um senão importante nisso: é que os salários jamais acompanham a elevação dos preços. Os aumentos de salários geralmente têm de ser conquistados com luta. São obtidos por uma ação coletiva deliberada que encontra resistência, ao passo que os preços são elevados pelas operações de mercado. $O$ trabalhador era contra isso. Em fins do século XV o salário de um dia do trabalhador na França correspondia a 4,3 quilos de carne; um século depois valia apenas 1,8 quilo". HUBERMAN. Op. Cit., p. 102.
} 
composição social estava bem polarizada economicamente, com uma classe nobre e outra composta de servos, sendo esta uma classe baixa que somente se ocupava do trabalho. O aparecimento da burguesia faz surgir, portanto, uma classe social intermediária, com anseios de galgar importância política que a possibilite influenciar nos negócios da administração pública, antes só privilégio da nobreza e do clero. E aqui começa a se desenhar as circunstâncias que logo adiante, no século XVIII, dará ensejo aos movimentos revolucionários, cujo ápice foi a Revolução Francesa de 1789, em que a burguesia, com o auxílio dos coevos expoentes da intelectualidade, consegue, então, inflamar toda a classe na qual estava inserida, para por fim ao regime absolutista, cujas consequências e projeções para o futuro eram, muito provavelmente, imprevistas pelos seus atores ${ }^{25}$.

\subsection{A Precarização do Trabalho}

Em meados do século XVIII, com o desenvolvimento da máquina a vapor, cuja fonte de energia era o carvão mineral, uma grande transformação ocorre nos meios de produção. A Inglaterra era detentora de grandes reservas desse mineral e foi, consequentemente, o berço da revolução industrial, onde o trabalho nas minas de carvão funcionava com características muito peculiares e condições totalmente insalubres.

As formas de extração do carvão mineral representa um capítulo de grande significância para a história do trabalho humano. O carvão que, desde o século XVI era encontrado e extraído de veios superficiais, vai se tornando cada vez mais importante e demandando a necessidade de descoberta de veios mais profundos, agravando cada vez mais as condições de trabalho, tornando-as ainda mais precárias e degradantes.

O trabalho passa, com o tempo, a ser realizado em minas de grandes profundidades, em que se empregavam homens, mulheres e até crianças, com jornadas de trabalho tão extensas quanto poderiam suportar os limites da resistência humana. A situação torna evidente que o trabalho humano se tornará, necessariamente, objeto de preocupações, tanto do ponto de vista econômico quanto social.

No século XVIII, como se sabe, o mundo ocidental passou por grande transformação jurídico-política, a partir das revoluções, cuja maior expressão foi representada pela Revolução Francesa de 1789 , em quando classe burguesa busca e consegue a conquista de espaço e importância política.

\footnotetext{
${ }^{25}$ Comparato acentua este ponto: "Durante todo o desenrolar do processo revolucionário, foi impossível aos coetâneos perceber qual o verdadeiro sentido da Revolução para o futuro, quais os seus efeitos duradouros e quais os meramente transitórios; tanto mais que estes últimos, pelo seu caráter extraordinário, impressionavam mais fundamente os espíritos. Afinal, é essa a regra geral em matéria de observação histórica. Somos todos, de certa forma, acometidos de hipermetropia; quanto mais próximos nos encontramos dos fatos históricos, menos conseguimos enxergá-los com nitidez". COMPARATO, Fábio Konder. A Afirmação Histórica dos Direitos Humanos. 4. ed., São Paulo: Saraiva, 2006, p. 142.
} 
A partir da trilogia Liberdade, Igualdade e Fraternidade fundam-se os princípios informadores das constituições que passaram a ser os documentos fundamentais dos Estados democráticos.

$\mathrm{Na}$ ânsia de se constituir sociedades livres em sua autoafirmação, ganhou relevo a instituição de Estados que não intervinham nas relações privadas, o que proporciona uma forma de contrato fundado unicamente na manifestação da vontade das partes, sem se levar em conta quaisquer diferenças sociais, políticas ou econômicas existentes entre os contratantes. Este Estado Liberal deixava, portanto, cada indivíduo à sua própria sorte, pois que a liberdade de contratar era a sua tônica ${ }^{26}$.

Esse total liberalismo contratual se refletia também nas relações trabalhistas. E tudo aliado à crescente industrialização não poderia trazer bons resultados para os trabalhadores, cujo poder de negociação - manifestação da vontade - não lograva resultados que lhe fossem minimamente favoráveis. Ao contrário, as condições subumanas eram cada vez mais evidentes nas relações trabalhistas, em que eram literalmente explorados homens, mulheres e crianças ${ }^{27}$.

A partir da virada do século XVIII para o século XIX, a associação do uso da propriedade privada, do capital e a força do trabalho assalariado caracterizam o capitalismo, que dará impulso a um desenvolvimento grandioso. Associado a isso, ocorre o desenvolvimento de novas técnicas de produção, assim como a ciência que passa a se desenvolver, proporcionando novas descobertas. Tudo faz com que se encaminhe para a revolução industrial, caracterizada pelo desenvolvimento de máquinas e ferramentais que facilitarão a produção.

Aí, consequentemente, se impõe uma especialização do trabalho, tendente a tornar o trabalhador ainda mais dependente da sua capacidade individual.

\footnotetext{
${ }^{26}$ A esse respeito, escreve Silva: "No Estado Liberal, com a nítida separação entre o Estado e a sociedade, assumiu extraordinário relevo a autonomia dos particulares, sendo-lhes deferida quase totalmente a formação da ordem privada". SILVA, Clóvis do Couto e. A Obrigação como Processo. Rio de Janeiro: Editora FGV, 2006, p. 25. No mesmo sentido, Nascimento: "A extinção das monarquias absolutas e o advento do Estado capitalista, resultado, na Inglaterra, das restrições à Coroa Britânica, do "Bill of Rights", de 1689, na França da revolução de 1789 e da "Declaração dos Direitos do Homem e do Cidadão", nos Estados Unidos da América do Norte, do movimento de independência e da "Declaração da Virgínia", de 1776, trazem como consequência, uma atitude de omissão do Estado diante dos problemas diretamente ligados ao interesse dos particulares, dentre os quais estava incluída a relação de trabalho. Assim, com a liberdade que a nãointerferência proporcionava, criaram-se todas as condições para o agravamento da situação dos trabalhadores". NASCIMENTO, Amauri Mascaro. Fundamentos do Direito do Trabalho. São Paulo: LTr, 1970, p. 26-27.

${ }^{27}$ "Se o patrão estabelecia as condições de trabalho a serem cumpridas pelos empregados, é porque, principalmente, não havia um direito regulamentando o problema. (...) Às vezes, eram impostos contratos verbais a longo prazo, até mesmo vitalícios; portanto, uma servidão velada, praticada especialmente em minas nas quais temia-se pela falta de mão de obra. É o que acontecia na indústria escocesa, na qual os trabalhadores eram comprados ou vendidos com os filhos, tanto assim que se fizeram necessários os decretos parlamentares de 1774 e 1799 suprimindo a servidão vitalícia dos mineiros escoceses". NASCIMENTO, Amauri Mascaro. Op. Cit., p. 20.
} 
Se aquela antiga característica do trabalho grupal havia dado lugar ao trabalho individual, este agora se torna também especializado, de forma a dividir a responsabilidade de fabricação de uma única peça entre vários trabalhadores. A pessoa do trabalhador já não tem importância, pois, em última análise, o que está em jogo é a produção, e o trabalhador representa simplesmente um instrumento para a consecução dos objetivos da indústria, porém sem qualquer consideração respeitante à pessoa.

Em meados do século XIX, ainda sob a vigência do Estado Liberal, em que o trabalhador fica relegado à sua própria capacidade de negociação, que de fato era quase nula, o indivíduo se vê cada vez mais sujeito ao império do poder do capital e da propriedade privada dos meios de produção. O carvão mineral é, então, fonte de energia de importância vital para esse processo produtivo, destinado a suprir um mercado cada vez mais ávido de consumo.

O trabalhador se vê em situação cada vez mais degradante e de miserabilidade, pois que Ihe é exigida produtividade cada vez maior, aliada a uma remuneração cada vez menor. E o trabalho nas minas de carvão alcança estágio realmente aviltante, em que a dignidade humana não merece qualquer consideração $0^{28}$.

Mas não eram somente os trabalhadores das minas de carvão que se sujeitavam às condições impostas pelo poder do capitalismo liberal. Todos aqueles cujo único produto que possuíam para venda era a sua força física estavam submetidos às mesmas imposições de produzir o máximo pelo menor salário possível ${ }^{29}$. Esta era e continua ainda a ser a tônica do sistema capitalista.

O século XIX contabilizou grandes movimentos em prol da valorização do trabalho e da proteção dos trabalhadores. A classe trabalhadora encontra apoio em pensadores que passam a questionar a relação de emprego como forma de sua exploração pelo poder do capital. Em 1848, o Manifesto do Partido Comunista escancara a revolta contra o capitalismo e passa a exigir o fim da exploração da classe operária, que classificava como proletária. Marx e Engels ${ }^{30}$ não poupam críticas à classe burguesa, recém-emergida e que, agora, se afigura como a responsável pelos abusos experimentados pelos proletários.

\footnotetext{
${ }^{28}$ Merece destaque na descrição de tais circunstâncias o romance de Zola, em que descreve a situação de miserabilidade em que viviam os mineiros de Montsou, ao norte da França, pelo realismo com que desenvolve a temática. Para bem retratar a situação o autor se serviu da realidade, tendo passado meses vivendo a prática como mineiro. ZOLA, Émile. Germinal. Tradução Silvana Salerno. São Paulo: Companhia das Letras, 2009, passim.

${ }^{29}$ As referências feitas por alguns historiadores àquela fase capitalismo são eloquentes, como esta de HUBERMAN: "Se um marciano tivesse caído naquela ocupada ilha da Inglaterra teria considerado loucos todos os habitantes da Terra. Pois teria visto de um lado a grande massa do povo trabalhando duramente, voltando à noite para os miseráveis e doentios buracos onde moravam, que não serviam nem para porcos; de outro lado, algumas pessoas que nunca sujaram as mãos com o trabalho, mas não obstante faziam as leis que governavam as massas, e viviam como reis, cada qual num palácio individual". HUBERMAN. Op. Cit., p. 176.

${ }^{30}$ MARX, Karl; ENGELS, Friedrich. Manifesto do Partido Comunista. Tradução de Pietro Nasseti. 2. ed., São Paulo: Editora Martin Claret, 2008, passim.
} 
Neste mesmo ano, a França que já vinha passando por conturbações políticas e enfrentando revoltas da classe trabalhadora, promulga uma nova Constituição em que o trabalho aparece como uma das bases da república ${ }^{31}$.

Os movimentos reivindicatórios por uma maior humanização das relações entre trabalho e capital se acentuam e ganham inclusive manifestações por parte da Igreja católica, como se verifica na encíclica RerumNovarum, do Papa Leão XIII, de 15 de maio de 1891, que já no primeiro parágrafo da sua introdução dá a dimensão dos conflitos que afligiam a sociedade na época.

A sede de inovações, que há muito tempo se apoderou das sociedades e as tem numa agitação febril, devia, tarde ou cedo, passar das regiões da política para a esfera vizinha da economia social. Efectivamente, os progressos incessantes da indústria, os novos caminhos em que entraram as artes, a alteração das relações entre os operários e os patrões, a influência da riqueza nas mãos dum pequeno número ao lado da indigência da multidão, a opinião enfim mais avantajada que os operários formam de si mesmos e a sua união mais compacta, tudo isto, sem falar da corrupção dos costumes, deu em resultado final um temível conflito $^{32}$.

Entretanto, tais movimentos não estavam adstritos à Europa. No México, os movimentos sindicais estavam em forte ebulição no começo do século XX. Tanto que a Constituição mexicana de 1917 é tida como marco histórico na afirmação do trabalho como direito social fundamental, pois foi no seu texto que, de forma pioneira, se inseriu como dever do Estado intervir nas relações de trabalho, com um extenso rol de direitos dos trabalhadores, limitações da jornada de trabalho e restrições ao trabalho de menores e de mulheres, bem como direitos especificamente destinados a estas. A inauguração de garantias constitucionais das relações de trabalho pela Constituição mexicana de 1917 influenciou as mudanças que, a partir daí se verificou nas legislações de cada país. A constituição alemã de 1919, de Weimar, é tida como segundo marco nessa direção, também com influência marcante nas constituições ocidentais futuras, porém já como sendo influenciada pela mexicana ${ }^{33}$.

\footnotetext{
${ }^{31}$ No item IV do seu preâmbulo, a Constituição francesa de 1848, traz expresso sobre a República: "IV - Ela tem por princípio a Liberdade, a Igualdade e a Fraternidade. Tem por base a Família o Trabalho, a Propriedade, a Ordem Pública". Apud COMPARATO, Fábio Konder. A Afirmação Histórica dos Direitos Humanos. 4. ed., São Paulo: Saraiva, 2006, p. 167.

${ }^{32}$ Disponível em <http://www.vatican.va>. Acesso em 14 nov. 2011.

${ }^{33}$ Nas palavras de Comparato: "Apesar das fraquezas e ambiguidades assinaladas, e malgrado sua breve vigência, a Constituição de Weimar exerceu decisiva influência sobre a evolução das instituições políticas em todo o Ocidente. O Estado democrático social, cujas linhas-mestras já haviam sido traçadas pela Constituição mexicana de 1917, adquiriu na Alemanha de 1919 uma estrutura mais elaborada, que veio a ser retomada em vários países após o trágico interregno nazi-fascista e a $2^{\mathrm{a}}$ Guerra Mundial". COMPARATO, Fábio Konder. Op. Cit., p.188.
} 


\section{A EXPLORAÇÃO DO TRABALHO ESCRAVO}

A Convenção Relativa à Escravidão ${ }^{34}$, de 25 de setembro de 1926 , em seu artigo $1^{\circ}, \S 1^{\circ}$, define escravidão como o estado ou condição de um indivíduo sobre o qual se exercem, total ou parcialmente, os atributos do direito de propriedade.

A origem da escravidão comporta algumas interpretações, porém levam, geralmente, à conclusão de que tal submissão do homem ao seu semelhante está ligada à força, a um poder de intimidação ou a uma dependência extrema. É de se considerar, entretanto, que a Bíblia traz referências várias à escravidão ${ }^{35}$, o que remete a uma ideia de que tal submissão de um ser humano a outro é de ocorrência antiga e de origem incerta ${ }^{36}$.

É certo também que a escravidão esteve presente entre as sociedades com características diversas, como serviçais domésticos ou como mão de obra produtiva. Com as grandes descobertas ocorridas a partir do século XVI, a escravidão surge como solução para a crescente necessidade de exploração das colônias, que demandava grande volume de mão de obra, cuja disputa pelos países colonizadores fez com que o tráfico se alastrasse pela Europa e suas colônias.

Se o capitalismo se serve da força de trabalho humano, o seu desenvolvimento não encontrou limites na busca de minimização de custos da mão de obra. E logo encontrou uma forma barata de utilização desse recurso, e da forma mais perversa possível - a escravidão.

Se antes a escravidão se fundamentava mais nas conquistas por guerras, ficando o prisioneiro em poder do vencedor na condição de cativo, agora, porém, a escravidão tem como fonte quase exclusiva o tráfico de negros africanos que, retirados de suas pátrias se tornam objetos de transações comerciais, sendo enquadrados na categoria de coisas, podendo ser adquiridos e vendidos, de acordo com a conveniência dos interessados.

\footnotetext{
${ }^{34}$ BITTAR, C. B. Eduardo; ALMEIDA, Guilherme Assis de. (organizadores). Mini-Código de Direitos Humanos. São Paulo: Editora Juarez de Oliveira, 2008, p. 581-582.

${ }^{35}$ Exemplo dessas referências está em Levítico 25:44 "Vossos escravos, homens ou mulheres, tomá-los-eis dentre as nações que vos cercam ; delas comprareis os vossos escravos, homens ou mulheres".

${ }^{36}$ Pétré-Grenouilleau assim inicia a sua obra sobre a história da escravidão: "Todos os grandes fenômenos da história têm seus mitos. Ainda encontramos em algumas obras uma história da qual eu, pessoalmente, não conheço a origem. Contam que, um dia, os canibais decidiram manter alguns prisioneiros a seu serviço, ao invés de devorá-los. Foi assim que surgiram os primeiros escravos. Essa história é interessante por mais de um motivo. De fato, o canibalismo remete à imagem da barbárie, ao mundo de antes da humanidade. Fazer a invenção da escravidão coincidir com os primeiros sinais de abrandamento do canibalismo é inseri-la nas próprias origens das sociedades humanas. É aceitar a ideia (ou querer que acreditemos) de que a escravidão está inevitavelmente ligada à vida em sociedade, de que esteve presente quase sempre por toda a parte". PÉTRÉ-GRENOUILLEAU, Oliver. A História da Escravidão. Tradução Mariana Echalar. São Paulo: Boitempo, 2009, p. 13.
} 
Ao chegarem aos países de destino eram submetidos a condições de trabalho subumano, pelo qual recebiam apenas a simples alimentação e a habitação, geralmente em condições precárias. A esses seres humanos não era dedicado qualquer tratamento digno, pois que como seres humanos não eram considerados.

Por mais aviltante que fosse tal situação, com o tempo o escravo negro até se acostumava com esta sua condição de "ser inferior", o que ia contribuindo para uma total falta de autoestima e criando a tendência de associação do negro à noção de raça inferior, que tantas distorções e conflitos causaram e ainda causam em sociedades diversas, mesmo ditas desenvolvidas.

A aceitação de sua situação e a resignação frente ao menosprezo talvez se deva ao condicionamento a que estão sujeitos os seres em geral. Qualquer situação, por mais desconfortável e degradante que seja, talvez poderá ser considerada normal por aquele que a ela esteja submetido, se não tiver experimentado situação diversa, ou se a ela estiver submetido desde a tenra idade $^{37}$. Razões outras podem nos conduzir ao sentimento de normalidade frente a situações que não podem ser aceitas como normais, como, por exemplo, a falta de oportunidade de desenvolvimento da capacidade de nos imaginar na posição do nosso semelhante. Daqueles que nasceram e cresceram aprendendo que a escravidão é algo natural, seria razoável esperar certa falta de sensibilidade para as condições desumanas impostas por tal regime. A falta de experiência de vida poderá acarretar distorções várias na forma de avaliação da situação dos nossos semelhantes, da mesma forma que a habitual convivência nos proporciona certo senso de normalidade. Assim é que, com o passar do tempo, a escravidão foi se tornando normal e aceito até pelos próprios escravos, com registro de alguns poucos movimentos reacionários que eram coibidos por meio da força.

Nesse contexto, e associada ao desenvolvimento do capitalismo do século XIX, a escravidão foi contemporânea do aviltamento do trabalho assalariado do operariado que crescia como categoria. O operariado sofrendo com o liberalismo presente nas relações de emprego do pujante capitalismo

\footnotetext{
${ }^{37}$ Nesse sentido, destacamos passagem da obra de Pétré-Grenouilleau, descrevendo as possibilidades de os escravos se verem livres das aflições a que eram expostos: "Alguns escravos escapavam de tudo isso quando se percebia que podiam render um bom resgate. Outros podiam ser resgatados depois de alguns anos, como Miguel de Servantes (1547-1616), autor de Dom Quixote, que foi escravo durante cinco anos. Era uma verdadeira provação, pelo que diz Willian Okeley, um inglês que foi escravo em Argel e, em 1675, publicou o relato do seu cativeiro. Ele escreveu: 'à medida que passou o tempo, nós nos acostumamos tão bem à escravidão que quase nos esquecemos da liberdade; nós nos tornamos bichos inconscientes da nossa servidão'“. PÉTRÉ-GRENOUILLEAU, Oliver. Op. Cit., p. 91. É o que, provavelmente, explica o fato da criança que conta com pouca experiência de vida aceitar com maior naturalidade do que um adulto a sua condição de doente ou deficiente físico. Varela nos dá um emocionante testemunho dessa realidade ao narrar a sua experiência com tratamento de crianças portadoras de câncer. VARELA, Dráusio. Por um Fio. São Paulo: Companhia das Letras, 2004, p. 61 e ss.
} 
dos países que se industrializavam e os escravos subjugados nas atividades predominantes nos países voltados ainda para as atividades primárias.

Houve situações em que o tráfico de escravos se transformou em negócio tão lucrativo que a sua finalidade precípua, qual seja, a utilização como mão de obra, foi relegada a um segundo plano. No Brasil, por exemplo, onde se escravizou também o índio, o comércio de escravos negros era objeto de disputas ${ }^{38}$.

Com a escravidão fica, então, evidenciada a falta de limites à exploração do trabalho humano como mera forma de acumulação de riquezas. Por este e por outros motivos o trabalho já foi associado ao sofrimento e a uma posição de inferioridade daqueles que dele dependem para a sua sobrevivência, talvez até em função da etimologia da palavra e por ter sido a escravidão a forma originária de trabalho ${ }^{39}$.

A abolição formal da escravidão, que em nosso país ocorreu em 1888, não foi promovida por motivos isentos de interesses capitalistas, pois os países que se industrializavam não desejavam que economias baseadas na utilização da mão de obra escrava - como a cultura do café, no Brasil continuassem a prosperar.

É necessária certa prudência ao se falar da abolição da escravatura, pois que o fato de estar esse regime nefasto juridicamente repelido, não é rara a ocorrência de diversas situações em que trabalhadores são submetidos a condição análoga à de escravo, possibilitando que ainda se tire proveito da exploração do trabalho humano cativo ${ }^{40}$.

O fato importante é que o trabalho escravo em muito contribuiu para o desenvolvimento do capitalismo, numa fase em que a industrialização não tinha

\footnotetext{
${ }^{38}$ Fausto noticia tal ocorrência: "Mas, se a introdução do trabalho escravo se explica dessa forma, por que se optou de preferência pelo negro e não pelo índio? A principal razão reside no fato de que o comércio internacional de escravos, trazidos da costa africana, era em si mesmo um negócio tentador, que acabou transformando no grande negócio da Colônia. Portugueses, holandeses e brasileiros, estes na fase final da Colônia, disputavam o controle dessa área. O tráfico representava, pois, uma fonte potencial de acumulação de riqueza e não apenas um meio de prover de braços a grande lavoura de exportação". FAUSTO, Boris. História concisa do Brasil. 2. ed., São Paulo: Editora da Universidade de São Paulo, Imprensa Oficial do Estado, 2008, p. 22. ${ }^{39} \mathrm{Na}$ expressão de Martins: "Trabalho vem do latim tripalium, que era uma espécie de instrumento de tortura de três paus ou uma canga que pesava sobre os animais. A primeira forma de trabalho foi a escravidão, em que o escravo era considerado apenas uma coisa, não tendo qualquer direito, muito menos trabalhista. O escravo, portanto, não era considerado sujeito de direito, pois era propriedade do dominus. Nesse período, constatamos que o trabalho escravo continuava no tempo, até de modo indefinido, ou mais precisamente até o momento em que o escravo vivesse ou deixasse de ter essa condição. Entretanto, não tinha nenhum direito, apenas o de trabalhar". MARTINS, Sergio Pinto. Direito do Trabalho. 25. ed., São Paulo: Atlas, 2009, p. 4.

40 "A novidade é que, a escravidão estando oficialmente abolida em todo o mundo, o que temos são situações de fato e não de direito. Isso mostra que a mentalidade das pessoas não evoluiu na mesma velocidade que o direito. Assim, a 'modernidade' da escravidão que persiste sob o nosso nariz depende em grande parte da persistência de mentalidades antigas do mundo 'moderno'. PÉTRÉ-GRENOUILLEAU, Oliver. Op. Cit., p. 98.
} 
assumido ainda um caráter globalizado. $\mathrm{O}$ trabalho assalariado veio substituir a mão de obra escrava, mesmo porque motivos de ordem política e moral passaram a influenciar a tomada de posição abolicionista na ordem mundial ${ }^{41}$.

Estas são razões que, em nosso sentir, torna impossível se falar de trabalho como direito fundamental sem uma referência, ainda que breve, ao trabalho escravo.

\section{O TRABALHO NAS CONSTITUIÇÕES BRASILEIRAS}

À época da outorga da Carta Magna de 1824, a primeira após a nossa independência proclamada em 1822, ainda se vivia sobre a influência dos movimentos reivindicatórios da França de 1789 e, portanto, sob a influência daqueles direitos de primeira geração, em que predominava a liberdade de contratação, livre da intervenção do Estado. É de se concluir daí que o Texto de então não seria veículo de grandes inovações.

Assim, a Constituição do Império se limitava a vetar a proibição de qualquer gênero de trabalho que não afrontasse os costumes, a segurança ou a saúde dos cidadãos. Em seu Título ${ }^{\circ}$, que trata das Disposições Gerais, e Garantias dos Direitos Civis e Políticos dos cidadãos Brasileiros, o artigo 179, inciso XXIV dispõe, in verbis:

XXIV. Nenhum genero de trabalho, de cultura, industria, ou commercio póde ser prohibido, uma vez que não se opponha aos costumes publicos, á segurança, e saude dos Cidadãos.

Como se vê, a preocupação estava limitada a proporcionar a liberdade tão em evidência na época.

Quando da promulgação da primeira Constituição republicana, a de 1891, as relações trabalhistas já se apresentavam de forma bastante conflituosa pela Europa. O partido comunista havia editado o seu manifesto em 1848. Os movimentos reivindicatórios ganhavam força embalados pelos ideais marxistas, e a Igreja católica manifestava suas preocupações, como já demonstrado. Entretanto, a nossa constituição de 1891, mesmo ano da Encíclica RerumNovarum, não logrou inovar com relação à de 1824, tendo como referência ao trabalho apenas a manutenção da liberdade de exercício nos moldes aproximados da sua antecedente.

No seu Título IV, Seção II, que trata da Declaração de Direitos, dispõe:

Art 72 - A Constituição assegura a brasileiros e a estrangeiros residentes no País a inviolabilidade dos direitos concernentes à liberdade, à segurança individual e à propriedade, nos termos seguintes:

\footnotetext{
${ }^{41}$ A Declaração Universal dos Direitos Humanos, elaborada em 1948, dispõe, em seu artigo $4^{\circ}$ : "Ninguém será mantido em escravidão ou servidão; a escravidão e o tráfico de escravo serão proibidos em todas as suas formas".
} 
$\S 24$ - É garantido o livre exercício de qualquer profissão moral, intelectual e industrial.

O constituinte brasileiro ainda não tinha um olhar para as mudanças que se desenhavam no âmbito das relações de trabalho. Não se pode perder de vistas que o Brasil havia recentemente abolido a escravidão e, portanto, não sofria os reflexos de movimentos trabalhistas que já se vinham observando na Europa.

A Constituição de 1934 é promulgada em um novo contexto histórico. O mundo já havia passado por uma guerra de dimensão mundial, que gerou consequências diversas.

O México já havia promovido inovações várias no campo do direito dos trabalhadores, com previsão de direitos acessórios vários. Na mesma direção havia caminhado a constituição de Weimar, de 1919. As experiências do pósguerra recomendavam preocupações com os aspectos sociais. A Constituição brasileira de 1934 não poderia estar indiferente a tais ocorrências, e promoveu garantias de direitos relativos ao trabalho em seu artigo 113 , item 34 , e um extenso rol de normas protetivas dos trabalhadores em seu artigo 121 e parágrafos, insertos no Título IV, que trata da Ordem Econômica e Social ${ }^{42}$. O artigo 121, trouxe a previsão do salário mínimo, jornada de trabalho limitada a oito horas diárias, repouso semanal, férias remuneradas, proibição de trabalho para menores de catorze anos, do trabalho noturno para menores de dezesseis anos e de trabalho insalubre para menores de dezoito anos e mulheres, entre outras. Não é de se estranhar que a Constituição trouxesse um rol extenso de previsões relativas ao trabalho vez que não se dispunha de legislação específica, além de a matéria se constituir em demanda relativamente nova no seio da sociedade, reclamando normatização urgente e imediata.

A Constituição de 1934 vigeu por pouco mais de três anos, tendo sido outorgada em 1937 uma nova Carta Magna. Esta continuou na mesma linha, trazendo em seu artigo 136, no capítulo dedicado à Ordem Econômica, a definição do trabalho como um dever social, e o artigo 137 trazia os parâmetros a que se deveria subordinar a legislação do trabalho. Cabe aqui observar que o Decreto-Lei $n^{\circ} 5.452$, de $1^{\circ}$ de maio de 1943 , Consolidação das Leis do Trabalho, foi instituído sob a égide da Carta Magna de 1937, disciplinado de forma ampla a legislação trabalhista.

A Constituição de 1946 mantém os mesmo direitos previstos na anterior de 1937, com algumas normas protetivas adicionais, como por exemplo, assistência aos desempregados, prevista no seu artigo 157, inciso XV.

\footnotetext{
${ }^{42}$ A Ordem Econômica e Social também representou uma inovação do Texto em comento. "A Constituição de 16.07.1934, originária do Governo Provisório instalado no País em 11.11.1930, teve a primazia de introduzir um capítulo dedicado à Ordem Econômica e Social em nossas Constituições". FERRARI, Irani. História do Trabalho (p. 13-72). In FERRARI, Irani; NASCIMENTO, Amauri Mascaro; MARTINS FILHO, Ives Gandra da Silva. História do Trabalho, do Direito do Trabalho e da Justiça do Trabalho. São Paulo: LTr, 1998, p. 55.
} 
A Constituição outorgada em 1967 também não inovou em relação ao trabalho, seguindo o que dispunham as suas antecedentes, permitindo, entretanto, o trabalho para menores a partir dos 12 anos, artigo 158, inciso X. Se a Constituição outorgada em 1967 não promoveu grandes mudanças em relação ao trabalho, a Emenda Constitucional de 17 de outubro de 1969, frequentemente referida como Constituição de 1969, manteve, nessa matéria, o conteúdo da Carta Magna emendada.

A Constituição da República Federativa do Brasil, de 1988, estabelece como um dos fundamentos do Estado Democrático de Direito os valores sociais do trabalho e da livre iniciativa, numa clara disposição do constituinte de dar ao trabalho o devido peso que este deve assumir na ordem econômica. Não por acaso, se junta aos demais fundamentos da República: soberania, cidadania, dignidade da pessoa humana e pluralismo político.

Estabelecido o livre exercício de qualquer trabalho, ofício ou profissão, no inciso XIII do artigo $5^{\circ}$, o artigo $6^{\circ}$ reforça o trabalho como direito social fundamental, ao dispor:

Art. $6^{\circ}$ São direitos sociais a educação, a saúde, o trabalho, a moradia, o lazer, a segurança, a previdência social, a proteção à maternidade e à infância, a assistência aos desamparados, na forma desta Constituição.

Não se pode perder de vista que os aludidos artigos $5^{\circ}$ e $6^{\circ}$ estão inseridos no Título II - Dos Direitos e Garantias Fundamentais, o que insere o trabalho dentre aqueles direitos sociais, chamados de segunda geração, demandantes de uma ação positiva do Estado para atender àqueles que dele necessitam.

Além de figurar entre os fundamentos do Estado brasileiro e como direito social fundamental, o trabalho se constitui em fundamento da Ordem Econômica, que tem entre os seus princípios a busca do pleno emprego, nos termos seguintes:

Art. 170. A ordem econômica, fundada na valorização do trabalho humano e na livre iniciativa, tem por fim assegurar a todos existência digna, conforme os ditames da justiça social, observados os seguintes princípios:

VIII - busca do pleno emprego;

Assim é que a Constituição de 1988 assume o trabalho humano como um dos valores a serem perseguidos na construção da justiça social, trazendo como disposição geral do Título VIII, da Ordem Social, que esta tem como base o primado do trabalho e como objetivo o bem-estar e a justiça sociais (art. 193).

\section{BREVES CONSIDERAÇÕES SOBRE OS DIREITOS FUNDAMENTAIS}

Para se tecer algumas considerações sobre os direitos fundamentais cumpre, preliminarmente, perquirir o significado da expressão "direitos fundamentais". E esta expressão tem merecido a atenção da doutrina no sentido de traçar os seus contornos, de forma a diferenciá-la da expressão 
"direitos humanos", vez que esta se empresta mais a direitos universalmente reconhecidos a todos os seres humanos, independentemente do espaço geográfico ${ }^{43}$.

Os direitos fundamentais, por sua vez, estariam atrelados a um sistema constitucional específico, constituindo o seu núcleo fundante, de validade no âmbito da soberania do respectivo país. Os direitos fundamentais se constituem assim em fundamentos de validade dos atos do Estado ${ }^{44}$, impondo a este um dever de agir de acordo com tais fundamentos. Vale dizer, os direitos fundamentais tem como pressuposto o Estado Democrático de Direito ${ }^{45}$, em que a Constituição configura uma limitação do poder estatal.

Os direitos fundamentais têm, entretanto, suas raízes fincadas em momentos históricos que antecedem à construção do Estado constitucionalista moderno. A sua origem está ligada a fundamentos religiosos, a partir dos quais o homem deve ter sua dignidade respeitada por sua condição de origem e semelhança a Deus, seu criador. De acordo com esse pensamento jusnaturalistas, o homem é portador de certos direitos inatos a serem por todos respeitados.

Tais direitos ganham projeção e significância jurídica a partir dos movimentos revolucionários tendentes a abolir o poder absoluto dos governantes, cujo documento inaugural é a Carta Magna do rei João Sem Terra, documento este extraído pelo baronato ${ }^{46}$ da Inglaterra de 1215. A Inglaterra marca 0

\footnotetext{
${ }^{43} \mathrm{Em}$ que pese sejam ambos os termos ('direitos humanos' e 'direitos fundamentais') comumente utilizados como sinônimos, a explicação corriqueira e, diga-se de passagem, procedente para a distinção é de que o termo 'direitos fundamentais' se aplica para aqueles direitos do ser humano reconhecidos e positivados na esfera do direito constitucional positivo de determinado Estado, ao passo que a expressão 'direitos humanos' guardaria relação com os documentos de direito internacional, por referir-se àquelas posições jurídicas que se reconhecem ao ser humano como tal, independentemente de sua vinculação com determinada ordem constitucional, e que, portanto, aspiram à validade universal, para todos os povos e tempos, de tal sorte que revelam um inequívoco caráter supranacional (internacional). SARLET, Ingo Wolfgang. A Eficácia dos Direitos Fundamentais. 10. ed., rev. atual. e ampl., Porto Alegre: Livraria do Advogado, 2009, p. 29. ${ }_{44}$ Porque constantes da Lei Fundamental, são os direitos fundamentais aqueles direitos que assumem também a específica função que a Constituição vem adquirindo na Europa e no resto do mundo, ao longo dos últimos cinquenta anos - em resultado de preceitos expressos, do papel proveniente da justiça constitucional e de uma crescente consciência difundida na comunidade jurídica. Se a Constituição é o fundamento da ordem jurídica, o fundamento de validade de todos os atos do Estado (como diz o art. $3^{\circ}$ da Constituição Portuguesa), direitos fundamentais são os direitos que, por isso mesmo, se impõem a todas as entidades públicas e privadas (conforme, por seu lado, afirma o art. $1^{\circ}$ ) e que incorporam os valores básicos da sociedade". MIRANDA, Jorge. Manual de Direito Constitucional. Tomo IV Direitos Fundamentais, 3. ed., rev. e atual. Coimbra: Coimbra Ed., 2000, p. 51-52.

${ }^{45} \mathrm{Na}$ lição de Bastos, "O Estado de Direito consiste na existência de uma ordem jurídica capaz de enunciar e tutelar os direitos de cada cidadão. Devem existir também direitos que protejam o cidadão das arbitrariedades do Estado, ou seja, deve haver direitos contra o próprio Estado. Vale dizer que o Estado de Direito está subordinado apenas ao direito." BASTOS, Celso Ribeiro. Curso de Teoria do Estado e Ciência Política. São Paulo: Celso Bastos Editora, 2002, p. 162.

${ }^{46}$ Azevedo nos dá conta das circunstâncias do nascimento de tal documento: "Quem examina a trajetória e o sentido histórico das garantias individuais, há de fixar, sem discrepância, o marco
} 
pioneirismo de tais movimentos que ali voltaram a ter lugar e maior intensidade no século XVII, quando em 1628, Edward Coke redigiu a Bill of Rights, documento importante na luta pelos ideais dos ingleses, apresentada ao rei Carlos I. Em 1689 o parlamento inglês ganha supremacia sobre o poder soberano dos reis por meio da Declaração de Direitos (Bill of Rights), de 1689. Nesta, institui-se a separação dos poderes, com a declaração de que o Parlamento é um órgão que tem como principal função a de se encarregar da defesa dos súditos perante o Rei, estabelecendo eleições livres para os seus membros ${ }^{47}$.

A constitucionalização dos direitos fundamentais, entretanto, ganha expressão somente a partir da Declaração dos Direitos do Homem e do Cidadão, fruto da revolução Francesa, de 1789, coeva dos movimentos por direitos que ocorriam também na América do Norte, que teve como marco a Declaração de Direitos da Virgínia, de 12 de junho de 1776. A partir daí tais direitos passam a merecer espaço nas constituições dos países democráticos.

Porém, apesar das preocupações de diversos países em eleger um rol de direitos fundamentais, os conflitos bélicos passaram a demonstrar que 0 ser humano ainda não dispunha de garantias contra tais ocorrências que ceifavam tantas vidas de civis inocentes e relegavam a planos secundários a defesa da dignidade humana. Tais conflitos se configuraram como oportunidades para o surgimento de idealistas extremistas e a ocorrência de genocídios como se verificou já na Primeira Guerra Mundial.

Da Segunda Guerra Mundial as consequências foram ainda mais nefastas, com a eliminação de grande número de civis e a contaminação de outros tantos, como ocorreu em Hiroshima e Nagasaki com o uso da bomba atômica.

Estava assim configurada a necessidade de uma tomada de providência no sentido de se garantir que catástrofes artificiais daquela natureza não mais ameaçasse a humanidade. Assim foi que em 1945 se criou a Organização das Nações Unidas, constituída inicialmente por 51 países, dentre eles o Brasil, cujos objetivos refletem as preocupações com a necessidade de engajamento dos diversos países componentes na perseguição de políticas garantidoras da paz universal e respeito aos direitos humanos fundamentais.

inicial de tais direitos na Carta Magna, extorquida pelos barões ingleses, em 1215, em face do arbitrário e desastroso reinado de João Sem-Terra. Em verdade, não se pode negar o extraordinário significado do Capítulo XXXIX da Magna Carta regisJohannis de libertatibusAnglicae, pois é, a partir dele, que 'Nullus líber homo capiatur, velimprisonetur, autdisseisiatur, aututlagetur, autexuletur, autaliquo modo destruatur, necsupereumibimus, necsupereummittemus, nisi per legale judicium pariumsuorumvel per legem terre'. Nenhum homem livre será detido ou preso, nem desapossado, nem declarado fora da lei, nem exilado, ou de outro modo arruinado, nem nós agiremos contra ele, ou mandaremos alguém fazê-lo, a não ser por meio de julgamento legal de seus pares ou segundo as leis da terra." AZEVEDO, Luiz Carlos de. Introdução à História do Direito. São Paulo: Revista dos Tribunais, 2007, p. 144-145.

${ }^{47}$ COMPARATO, Fábio Konder. A Afirmação Histórica dos Direitos Humanos. 4. ed., São Paulo: Saraiva, 2006, p. 94. 
A Declaração Universal dos Direitos Humanos, vertida pela ONU reflete, então, o coroamento do longo período marcado por movimentos como aquele primeiro dos idos do século XIII, quando o baronato extrai o primeiro documento limitador do poder soberano ${ }^{48}$. Uma leitura atenta do preâmbulo dessa Declaração proporciona a clara percepção da situação de insegurança em que se via a humanidade em relação aos direitos humanos fundamentais.

\section{Preâmbulo}

Considerando que o reconhecimento da dignidade inerente a todos os membros da família humana e de seus direitos iguais e inalienáveis é o fundamento da liberdade, da justiça e da paz no mundo,

Considerando que o desprezo e o desrespeito pelos direitos humanos resultaram em atos bárbaros que ultrajaram a consciência da Humanidade e que o advento de um mundo em que os todos gozem de liberdade de palavra, de crença e da liberdade de viverem a salvo do temor e da necessidade foi proclamado como a mais alta aspiração do ser humano comum,

Considerando ser essencial que os direitos humanos sejam protegidos pelo império da lei, para que o ser humano não seja compelido, como último recurso, à rebelião contra a tirania e a opressão,

Considerando ser essencial promover o desenvolvimento de relações amistosas entre as nações,

Considerando que os povos das Nações Unidas reafirmaram, na Carta da ONU, sua fé nos direitos humanos fundamentais, na dignidade e no valor do ser humano e na igualdade de direitos entre homens e mulheres, e que decidiram promover o progresso social e melhores condições de vida em uma liberdade mais ampla,

Considerando que os Estados-Membros se comprometeram a promover, em cooperação com as Nações Unidas, o respeito universal aos direitos e liberdades humanas fundamentais e a observância desses direitos e liberdades,

Considerando que uma compreensão comum desses direitos e liberdades é da mais alta importância para o pleno cumprimento desse compromisso, Agora portanto

A ASSEMBLÉIA GERAL proclama A PRESENTE DECLARAÇÃO UNIVERSAL DOS DIREITOS HUMANOS como o ideal comum a ser

\footnotetext{
${ }^{48}$ Araújo sintetiza tal historicidade: "Os direitos fundamentais têm caráter histórico, isto é, se formos rebuscar seus antecedentes, encontraremos uma cadeia evolutiva, no pico da qual eles se situam. Os direitos fundamentais nasceram com o cristianismo. A doutrina cristã elevava o homem à situação de semelhança a Deus, indicando a igualdade como um dos pressupostos fundamentais. Assim, o ser humano foi alçado a um patamar de dignidade. Depois desse período, a discussão sobre direitos humanos ficou adormecida, vindo a ser despertada com o advento das declarações de direitos humanos. Dentre elas podemos citar a Magna Charta Libertarum, de 1215, a Declaração do Bom Povo da Virgínia, de 1776, e a Declaração de Direitos do Homem e do Cidadão, de 1789, sobrevindo a Declaração Universal de Direitos do Homem, da Organização das Nações Unidas, em 1948. ARAÚJO, Luiz Alberto David; NUNES JÚNIOR, Vidal Serrano. Curso de Direito Constitucional. São Paulo: Saraiva, 2003, p. 88.
} 
atingido por todos os povos e todas as nações, com o objetivo de que cada indivíduo e cada órgão da sociedade, tendo sempre em mente esta Declaração, se esforce, através do ensino e da educação, por promover o respeito a esses direitos e liberdades, e, pela adoção de medidas progressivas de caráter nacional e internacional, por assegurar o seu reconhecimento e a sua observância universal e efetiva, tanto entre os povos dos próprios Estados-Membros, quanto entre os povos dos territórios sob sua jurisdição ${ }^{49}$.

Tal não significa, entretanto, que os direitos humanos tenham alcançado o pleno respeito e consideração, pois que muitas carências ainda se observam para que se torne plena a sua efetivação ${ }^{50}$. Ainda se verificam formas várias de exclusão de grupos ou pessoas do acesso a condições dignas de vida, sem considerar que muitos inocentes civis continuam a perder a vida na condição de vítimas indefesas de conflitos para os quais não contribuíram.

\subsection{Direitos Fundamentais e suas Gerações}

Os direitos fundamentais têm como marco de sua constitucionalização os movimentos iluministas do século XVIII, marcadamente com os acontecimentos da época da Revolução Francesa de 1789 e outros movimentos por direitos individuais que ocorriam na América do Norte, como já se disse linhas atrás. Tais direitos têm como principal motivação as reivindicações por liberdades frente ao Estado absolutista.

Assim é que a tais direitos passou a doutrina a se referir como direitos de primeira geração ou direitos de defesa, quais sejam aqueles direitos que demandam do Estado uma ação negativa, no sentido de não intervenção numa determinada esfera de autonomia individual na qual não poderá este mesmo Estado intervir, notadamente o direito à vida, a liberdade, à propriedade e à igualdade $\mathrm{e}^{51}$.

É inevitável perceber que os movimentos revolucionários dos franceses do século XVIII clamando por liberdade, igualdade e fraternidade não estavam endereçados a todos os seres humanos, pois que as mulheres, bem como os escravos, continuavam à margem de tais pretensões.

A liberdade de atuação dos particulares sem a intervenção do poder estatal trouxe consequências inesperadas e indesejáveis, pois que as relações entre os particulares passaram a ser dirigidas por um caráter de liberdade em que não havia qualquer intervenção moderadora das diferenças de caráter econômico ou social, de sorte que a autonomia privada era o que prevalecia

\footnotetext{
${ }^{49}$ Disponível em <http://www.direitoshumanos.usp.br> Acesso em 04 dez. 2011.

${ }^{50}$ Nos dizeres de Bobbio, "O problema fundamental em relação aos direitos do homem, hoje, não é tanto o de justificá-los, mas de protegê-los. Trata-se de um problema não filosófico, mas político. BOBBIO, Norberto. A Era dos Direitos. Tradução de Carlos Nelson Coutinho; Apresentação de Celso Lafer. Rio de Janeiro: Elsevier, 2004, p. 23.

${ }^{51}$ SARLET, Ingo Wolfgang. (organizador). Constituição, Direitos Fundamentais e Direito Privado. Porto Alegre: Livraria do Advogado, 2010, p. 46-47.
} 
nas relações negociais de natureza particular. A autonomia privada, como bem refere Ferri, denota certo poder ${ }^{52}$ que, entretanto, não se pode atribuir ao trabalhador em uma relação que comporta desigualdade, pois que ele depende totalmente do seu trabalho para sobreviver. E assim as classes menos favorecidas passaram a ser compelidas a defenderem seus interesses por sua conta e risco perante os mais poderosos do ponto de vista econômico ou social.

Como já se acentuou, tais circunstâncias tiveram consequências drásticas, principalmente nas condições de trabalho e emprego, pois que os trabalhadores se viam compelidos a oferecer a sua força de trabalho a preços (salários) que geralmente ficavam aquém do mínimo necessário para a sobrevivência.

O século XIX se caracterizou pela eclosão de movimentos reivindicatórios que reclamavam justiça social, impondo, com o tempo, a emergência de garantias de uma atuação positiva do Estado no sentido de promover justiça social, o que caracterizou aquilo que a doutrina trata como direitos de segunda geração.

Se os direitos de primeira geração demandam do Estado uma ação negativa, os de segunda geração, ao contrário, demandam uma ação positiva, vale dizer, deve reunir esforços e recursos para garantir o atendimento das necessidades sociais dos seus administrados.

Os direitos de segunda geração se caracterizam, portanto, pela necessária assistência do Estado em favor da garantia de um mínimo existencial a cada indivíduo. Dentre esses direitos estão a saúde, a educação, o trabalho, o lazer, a segurança e a previdência social.

Na questão do trabalho, tem grande relevo a Constituição mexicana ${ }^{53}$ de 1917, pelo pioneirismo no trato aprofundado e detalhado dos direitos trabalhistas, impondo limitação da jornada de trabalho, estabelecendo férias e descanso semanal remunerado, dentre tantos outros.

\footnotetext{
52 "La autonomia privada no essóloni principalmente liberdad; sus manifestaciones no son mero ejercicio de underecho subjetivo, como loson andar o arar las fincas próprias. La autonomia privada es, ante todo, poder, y los negócios jurídicos sonmanifestación de poder". FERRI, Luigi. La Autonomia Privada. Madrid: Editorial Revista de Derecho Privado, 1969, p. 297.

${ }^{53}$ Dispõe o artigo 123, inciso XXXI, da citada constituição: XXXI. La aplicación de lãs leyes del trabajo corresponde a las autoridades de los Estados, en sus respectivas jurisdicciones, pero es de la competencia exclusiva de las autoridades federales em los asuntos relativos a: (...) b. Entre los Poderes de la Unión, el Gobierno del Distrito Federal y sus trabajadores: I. La jornada diaria máxima de trabajo diurna y nocturna será de ocho y siete horas, respectivamente. Las que excedan serán extraordinarias y se pagarán con un ciento por ciento más de la remuneración fijada para el servicio ordinarios. Em ningún caso el trabajo extraordinário poderá exceder de tres horas diárias ni de três veces consecutivas; II. Por cada seis días de trabajo disfrutará el trabajador de un día de descanso, cuando menos, com goce de salario íntegro; III. Los trabajadores gozarán de vacaciones, que nunca serán menores de veinte dias al año. Disponível em <www.dhnet.org.br> Acesso em 04 dez. 2011.
} 
A Constituição de Weimar, de 1919, tem também grande importância nessa mudança de fundamentos dos direitos trabalhistas ${ }^{54}$ e sociais. A Alemanha, recém-saída de uma guerra que lhe deixara um saldo social extremamente negativo, positivou nessa Constituição vários dispositivos de caráter social protetivo.

Após a consagração dos direitos sociais, e com a ocorrência da Segunda Guerra Mundial, passa-se a observar uma preocupação com a necessidade de se dedicar atenção aos direitos relacionados à paz, ao meio ambiente, qualidade de vida, autodeterminação dos povos, dentre outros, o que se convencionou chamar de direitos de terceira geração. Esses direitos não encerram as chamadas gerações de direitos, pois se refere a doutrina a direitos de quarta e até de quinta e sexta gerações ${ }^{55}$.

\section{O TRABALHO COMO SUSTENTAÇÃO DA DIGNIDADE DA PESSOA HUMANA}

É necessário ter em conta que a pessoa humana se realiza por meio do seu trabalho, sendo este o meio pelo qual o homem alcança a plenitude da sua dignidade ${ }^{56}$. Significa que o produto do trabalho é a exteriorização do próprio indivíduo que o executa. Portanto, àquele que não é dada a oportunidade de trabalho se estará impondo uma dupla condição de existência indigna $^{57}$.

Ademais, na sociedade moderna o trabalho simboliza a possibilidade de realização pessoal, materializada na possibilidade de consumo dos bens e produtos a que os indivíduos são frequentemente "convidados" a experimentar.

\footnotetext{
${ }^{54}$ É o texto do artigo 163 da Constituição de Weimar: Art. 163. Sem prejuízo de sua liberdade pessoal, todos os alemães têm o dever moral de utilizar suas forças físicas e espirituais para o bem da comunidade. A todo alemão dá-se a possibilidade de prover à sua subsistência pelo seu trabalho. Enquanto não se lhe puder proporcionar uma oportunidade de trabalho, cuidar-se-á de suas necessidades de subsistência. As particularidades locais serão atendidas mediante leis especiais do Estado central. Apud COMPARATO, Fábio Konder. A Afirmação Histórica dos Direitos Humanos. 4. ed., São Paulo: Saraiva, 2006, p. 195. A partir deste texto é possível perceber a preocupação do constituinte alemão com o trabalhador que se visse ao desamparo, configurando a tendência de atenção para com os direitos sociais que os Estados passaram a assumir a partir daquele início de século.

${ }^{55}$ SARLET, Ingo Wolfgang. (organizador). Constituição, Direitos Fundamentais e Direito Privado. Porto Alegre: Livraria do Advogado, 2010, p. 45.

${ }^{56}$ Dignidade, do latim dignitas, que significa merecimento, respeito, nobreza. Dignidade é qualidade. Algo relativo à moral, respeito ou valor. Logo, a proposição 'dignidade da pessoa humana' representa o valor, a qualidade intrínseca do homem enquanto ser. SIQUEIRA JR., Paulo Hamilton. A Dignidade da Pessoa Humana no Contexto da Pós-modernidade. p. 251-276. In MIRANDA, Jorge; SILVA, Marco Antonio Marques da (coord.). Tratado Luso-brasileiro da Dignidade Humana. São Paulo: Quartier Latin, 2008. p. 252.

${ }_{57}$ Nas palavras de Aldacy Rachid Coutinho, "O trabalho é salário, mas salário não é tudo; trabalho sempre será um processo de identificação dos momentos de produção social, reinventada a cada momento e a conquista de condições dignas de vida expressas em direitos". COUTINHO, Aldacy Rachid. A Autonomia Privada: em busca da defesa dos direitos fundamentais dos trabalhadores p. 159-173. In SARLET, Ingo Wolfgang. (organizador). Constituição, Direitos Fundamentais e Direito Privado. Porto Alegre: Livraria do Advogado, 2010, p. 161.
} 
Mas muito acima disto está a mera necessidade de sobrevivência, mormente para população como a brasileira, em que se verificam grandes desigualdades sociais e culturais, onde a garantia de oportunidade de trabalho se faz ainda mais necessária e urgente.

E o trabalho envolve também um conteúdo de ordem social importante que mais se evidencia quando o indivíduo se vê sem ocupação ${ }^{58}$. Daí porque o conteúdo principiológico da busca do pleno emprego previsto no artigo 170, inciso VIII, da Constituição Federal, deve ser perseguido de forma incansável.

A dignidade da pessoa humana como fundamento do Estado brasileiro tem sido muito realçada, mas não será alcançada pela pessoa que não puder contar com uma oportunidade de trabalho ${ }^{59}$. É por meio do trabalho que o indivíduo se torna côncio da sua utilidade social e se vê valorizado na sua existência. Por outro lado, é sabido que o trabalho sem utilidade, quando claro na consciência do indivíduo, poderá ter o efeito de lhe causar danos psicológicos. Tanto assim, que há relatos de utilização do trabalho inútil como forma de tortura nos campos nazistas de concentração ${ }^{60}$.

Por essas razões é que, em nosso sentir, as políticas governamentais devem se voltar para o atendimento dos princípios constitucionais expressos

\footnotetext{
58 "O trabalho sempre preservou o homem de sua própria destruição e o impeliu a interagir, unindo-se a outro ou a outros. Seja na caça, seja na pesca, seja na fabricação de instrumentos para a execução de serviços, o trabalho sempre foi um fator individual de conquista e também um fator social de cooperação na busca de idênticos ideais. A espécie humana, de geração a geração, mentem-se viva pelo trabalho, sob a forma de cooperação ou trabalho coletivo, determinando entre os indivíduos participantes, relações sociais que são de ordem econômica, pela produção, distribuição e troca de produtos; de ordem ética, por normas religiosas, morais e jurídicas e que regulam a vida de cada um em meio à corporação, classe ou sociedade". FERRARI, Irani. História do Trabalho (p. 13-72). In FERRARI, Irani; NASCIMENTO, Amauri Mascaro; MARTINS FILHO, Ives Gandra da Silva. História do Trabalho, do Direito do Trabalho e da Justiça do Trabalho. São Paulo: LTr, 1998, p. 23-24.

59 "Uma palavra sobre esse importante princípio. Erguido, em 1988, como fundamento do estado democrático de Direito, o princípio da dignidade da pessoa humana vem fundando as mais diversas decisões judiciais e vem sendo recolhido para ações governamentais e pleitos cobrados dos cidadãos. É natural essa utilização que, às vezes, pode ser desmedida. O país passa por um processo de resgate de direitos e sente a necessidade de buscar, no Poder Judiciário, muito dos pleitos que não lhe foram deferidos por um Poder Legislativo que se encontra distante, com valores próprios, muitas vezes, completamente diferentes da vontade popular. O princípio da dignidade da pessoa humana, de outro lado, é ancoradouro fácil para qualquer decisão judicial. E, reconhecemos, não há escala na aplicação do princípio". ARAÚJO, Luiz Alberto David. A Proteção Constitucional da Pessoas com Deficiência e o Cumprimento do Princípio da Dignidade Humana, p. 203-211. In MIRANDA, Jorge; SILVA, Marco Antonio Marques da (coord.). Tratado Luso-brasileiro da Dignidade Humana. São Paulo: Quartier Latin, 2008. p. 210.

60 "Depois de 9 meses, Julio e o irmão foram levados para Auschwtiz. Ficaram apenas 24 horas, pois ainda tinham forças para trabalhar, e foram transportados para Mauthausen. Lá ficaram algum tempo fazendo um trabalho cujo objetivo era destruir psicologicamente um ser humano, coisa que os alemães aprenderam a fazer com perfeição durante a Guerra. O "trabalho" de Julio era levar pedras de um lado para o outro e trazê-las de volta, horas a fio, dia após dia, semana após semana com uma ração mínima de comida e água". PITLIUK, Marcio. O Holocausto Judeu e outros Genocídios. Disponível em <http://www.ensinosobreholocausto.com.br/downloads/ jornada2/conteudo11.pdf>. Acesso em 08 dez. 2011.
} 
que elegem o trabalho como um direito social fundamental a ser garantido a todos como elemento concretizador da dignidade da pessoa humana. ${ }^{61} \mathrm{Tal}$ dever se torna tanto mais exigível quanto mais desigual é a sociedade e quanto maior é a parcela da população que não dispõe de educação formal que a capacite para a concorrência em igualdade de condições em um mercado de trabalho cada vez mais competido, como é o caso da população brasileira.

\section{CONCLUSÕES}

O trabalho, ao evoluir, em concomitância com o desenvolvimento da civilização, tem representado constante fator de autoafirmação da pessoa humana, de forma a demandar atenção por parte de toda a sociedade.

O direito ao trabalho é direito fundamental que se constitui em dever do Estado, vinculado à garantia de atendimento ao fundamento da dignidade da pessoa humana, na medida em que o indivíduo que não dispõe de uma oportunidade de trabalho não dispõe das possibilidades mínimas de autorrealização ou de sobrevivência.

A construção de uma sociedade livre, justa e solidária; a garantia do desenvolvimento nacional; a erradicação da pobreza e da marginalização e redução das desigualdades sociais e regionais; a promoção do bem de todos, sem preconceitos de origem, raça, sexo, cor, idade e quaisquer outras formas de discriminação. Compõem estes os objetivos fundamentais da República Federativa do Brasil. Certamente o trabalho está presente, de forma direta ou indireta em cada um destes objetivos.

Entretanto, apesar dos objetivos da solidariedade, da erradicação da pobreza e da marginalização e da vedação de quaisquer formas de preconceitos, o que se percebe é a clara discriminação e a falta de incentivos e alternativas na busca de oportunidades de trabalho para uma considerável parcela da população que não dispõe de educação. Os analfabetos e semianalfabetos praticamente são excluídos do mercado formal de trabalho, compondo uma grande parcela da população que é colocada à margem dos direitos fundamentais mais elementares, ficando apartada das garantias de uma vida digna.

De tudo se deduz ser o direito social fundamental ao trabalho, previsto no artigo $6^{\circ}$ da Constituição da República Federativa do Brasil, de 1988, um dever do Estado e da sociedade brasileira, para que se possa proporcionar a todos que dependam das suas próprias forças físicas ou intelectuais a oportunidade de ter acesso a um trabalho como forma de garantia da sua sobrevivência em condições mínimas de uma vida digna.

\footnotetext{
${ }^{61}$ Como salienta Sarlet: "Com efeito, também os assim denominados direitos sociais, econômicos e culturais, sejam na condição de direitos de defesa (negativos), seja na sua dimensão prestacional (atuando como direitos positivos), constituem exigência e concretização da dignidade da pessoa humana". SARLET, Ingo Wolfgang. Dignidade da Pessoa Humana e Direitos Fundamentais na Constituição Federal de 1988. 9. ed., rev. atual. Porto Alegre: Livraria do Advogado Editora, 2012, p. 108.
} 
Enquanto não forem minimizadas as carências da área educacional, será maior a responsabilidade social na busca de solução para a garantia de efetividade dos direitos fundamentais dos prejudicados, e com grande importância dentre eles está o direito ao trabalho.

\section{REFERÊNCIAS BIBLIOGRÁFICAS}

ARAÚJO, Luiz Alberto David; NUNES JÚNIOR, Vidal Serrano. Curso de Direito Constitucional. São Paulo: Saraiva, 2003.

AZEVEDO, Luiz Carlos de. Introdução à História do Direito. São Paulo: Revista dos Tribunais, 2007.

BASTOS, Celso Ribeiro. Curso de Teoria do Estado e Ciência Política. São Paulo: Celso Bastos Editora, 2002.

BITTAR, C. B. Eduardo; ALMEIDA, Guilherme Assis de. (organizadores). Mini-Código de Direitos Humanos. São Paulo: Editora Juarez de Oliveira, 2008.

BOBBIO, Norberto. A Era dos Direitos. Tradução de Carlos Nelson Coutinho; Apresentação de Celso Lafer. Rio de Janeiro: Elsevier, 2004.

COMPARATO, Fábio Konder. A Afirmação Histórica dos Direitos Humanos. 4. ed., São Paulo: Saraiva, 2006.

ENGELS, Friedrich. A Origem da Família, da Propriedade e do Estado. Tradução de H. Chaves. Lisboa: Editora Presença, 1976.

FAUSTO, Boris. História concisa do Brasil. 2. ed., São Paulo: Editora da Universidade de São Paulo, Imprensa Oficial do Estado, 2008.

FERRARI, Irani; NASCIMENTO, Amauri Mascaro; MARTINS FILHO, Ives Gandra da Silva. História do Trabalho, do Direito do Trabalho e da Justiça do Trabalho. São Paulo: LTr, 1998.

FERRI, Luigi. La Autonomia Privada. Madrid: Editorial Revista de Derecho Privado, 1969. HUBERMAN, Leo. História da Riqueza do Homem. Tradução de Waltensir Dutra. Rio de Janeiro: LTC Editora, 1986.

IANNI, Octavio. Teorias de Estratificação Social - Leituras de Sociologia. São Paulo, Companhia Editora Nacional, 1973.

LE GOFF, Jacques. As Raízes Medievais da Europa. Tradução de Jaime A. Clasen. Petrópolis, RJ: Vozes, 2007.

MARTINS, Sergio Pinto. Direito do Trabalho. 25. ed., São Paulo: Atlas, 2009.

MARX, Karl; ENGELS, Friedrich. Manifesto do Partido Comunista. Tradução de Pietro Nasseti. 2. ed., São Paulo: Editora Martin Claret, 2008.

MERCURE, Daniel; SPURK, Jan. (orgs). O Trabalho na História do Pensamento Ocidental. Tradução de Patrícia Chittoni Ramos e Sônia Guimarães Taborda. Petrópolis, RJ: Vozes, 2006.

MIRANDA, Jorge; SILVA, Marco Antonio Marques da (coord.). Tratado Luso-brasileiro da Dignidade Humana. São Paulo: Quartier Latin, 2008.

MIRANDA, Jorge. Manual de Direito Constitucional. Tomo IV Direitos Fundamentais, 3. ed., rev. e atual. Coimbra: Coimbra Ed., 2000.

NASCIMENTO, Amauri Mascaro. Fundamentos do Direito do Trabalho. São Paulo: LTr, 1970. 
PÉTRÉ-GRENOUILLEAU, Oliver. A História da Escravidão. Tradução Mariana Echalar. São Paulo: Boitempo, 2009.

RIPERT, Georges. Aspectos Jurídicos do Capitalismo Moderno. Campinas, SP: Red Livros, 2002.

SARLET, Ingo Wolfgang. A Eficácia dos Direitos Fundamentais. 10. ed., rev. atual. e ampl., Porto Alegre: Livraria do Advogado, 2009.

Dignidade da Pessoa Humana e Direitos Fundamentais na Constituição Federal de 1988. 9. ed., rev. atual. Porto Alegre: Livraria do Advogado Editora, 2012.

SARLET, Ingo Wolfgang. (organizador). Constituição, Direitos Fundamentais e Direito Privado. Porto Alegre: Livraria do Advogado, 2010.

SILVA, Clóvis do Couto e. A Obrigação como Processo. Rio de Janeiro: Editora FGV, 2006.

VARELA, Dráusio. Por um Fio. São Paulo: Companhia das Letras, 2004.

ZOLA, Émile. Germinal. Tradução Silvana Salerno. São Paulo: Companhia das Letras, 2009.

\section{Na Internet}

www.dhnet.org.br

http://www.direitoshumanos.usp.br

http://www.ensinosobreholocausto.com.br

http://www.vatican.va 